\title{
OPTIMIZATION OF BIOLOGICAL SHIELD FOR BORON NEUTRON CAPTURE CANCER THERAPY (BNCT) AT KARTINI RESEARCH REACTOR
}

\author{
Gani Priambodo ${ }^{1}$, Fahrudin Nugroho ${ }^{1}$, Dwi Satya Palupi ${ }^{1}$, R. Zailani ${ }^{2}$, Y. Sardjono ${ }^{3}$ \\ ${ }^{1}$ Department of Physics, Gadjah Mada University, \\ Sekip Utara, Bulaksumur, Sinduadi, Mlati, Yogyakarta 55281 \\ ${ }^{2}$ Department of Physics, Semarang State University, \\ Kampus Unnes Sekaran, Gunungpati, Semarang, Jawa Tengah 50229 \\ ${ }^{3}$ Center for Accelerator Science and Technology, National Nuclear Energy Agency (BATAN), \\ Jl. Babarsari, Kotak Pos 6101 Ykbb, Yogyakarta 55281 \\ Diterima editor: 26 Agustus 2017 \\ Diperbaiki: 23 September 2017 \\ Disetujui untuk publikasi: 3 Oktober 2017
}

\begin{abstract}
OPTIMIZATION OF BIOLOGICAL SHIELD FOR BORON NEUTRON CAPTURE CANCER THERAPY (BNCT) AT KARTINI RESEARCH REACTOR. A study to optimize a model of neutron radiation shielding for BNCT facility in the irradiation room has been performed. The collimator used in this study is a predesigned collimator from earlier studies. The model includes the selection of the materials and the thickness of materials used for radiation shield. The radiation shield is required to absorb leaking radiation in order to protect workers at the threshold dose of $20 \mathrm{mSv} / \mathrm{year}$. The considered materials were barite concrete, paraffin, stainless steel 304 and lead. The leaking neutron radiation dose rates have been determined using Monte Carlo N Particle Version Extended (MCNPX) with a radiation dose limit rate that is less than $10 \mu \mathrm{Sv} /$ hour. This dose limit is in accordance with BAPETEN regulation related the threshold dose for workers, in which the working duration is 8 hours per day and 5 days per week. It is recommended that the best model for the irradiation room has a dimension $30 \mathrm{~cm}$ width, $30 \mathrm{~cm}$ length, $30 \mathrm{~cm}$ height and a main layer of irradiation room shielding made from the material paraffin which is $68 \mathrm{~cm}$ thickness on the left side and bottom of the irradiation room, $70 \mathrm{~cm}$ thickness on the right side of the iradiation room, $45 \mathrm{~cm}$ thickness on the front of the irradiation room and $67 \mathrm{~cm}$ thickness on the top of the irradiation room. The additional layers of $15 \mathrm{~cm}$ and $10 \mathrm{~cm}$ thickness are used along with paraffin in order to reduce the intensity of primary radiation from piercing the beamport after two primary layers. There is no neutron radiation leakage in this model.
\end{abstract}

Keywords: Radiation shielding, BNCT, MCNPX, radiation dose rate, piercing beamport.

\begin{abstract}
ABSTRAK
OPTIMASI PERISAI RADIASI NEUTRON FASILITAS RUANGAN IRADIASI UNTUK BORON NEUTRON CAPTURE CANCER THERAPY (BNCT) DENGAN SUMBER BEAMPORT TEMBUS REAKTOR KARTINI. Telah dilakukan pemodelan perisai radiasi neutron untuk fasilitas Boron Neutron Capture Therapy (BNCT) pada sekeliling ruangan iradiasi. Pemodelan mencakup pemilihan bahan dan tebal yang digunakan untuk perisai radiasi. Perisai diharuskan mampu menahan radiasi yang keluar ruangan sehingga dosis radiasi berada di bawah ambang dosis bagi pekerja radiasi sebesar 20 mSv/tahun. Bahan yang dipertimbangkan adalah beton barit, paraffin, stainless steel 304 dan timbal. Perhitungan laju dosis neutron epitermal dilakukan dengan menggunakan program Monte Carlo $N$ Particle Version Extended (MCNPX) dengan batasan laju dosis radiasi kurang dari $10 \mu \mathrm{Sv} / \mathrm{jam}$, sesuai dengan peraturan Kepala BAPETEN mengenai batas ambang laju dosis pekerja radiasi, dengan asumsi perhitungan waktu kerja 8 jam per hari dan 5 hari per minggu. Desain pertama dari empat desain yang telah dibuat kemudian dipilih sebagai desain yang direkomendasikan dengan laju dosis di bawah batas ambang $10 \mu$ Sv/jam. Ruangan iradiasi memiliki dimensi panjang $30 \mathrm{~cm}$, lebar $30 \mathrm{~cm}$ dan tinggi $30 \mathrm{~cm}$. Lapisan utama perisai pada desain pertama berbahan paraffin setebal $68 \mathrm{~cm}$ pada sisi kiri dan bawah ruangan, $70 \mathrm{~cm}$ pada sisi kanan ruangan, $45 \mathrm{~cm}$ pada sisi depan ruangan dan $67 \mathrm{~cm}$ pada sisi atas ruangan. Paraffin setebal $15 \mathrm{~cm}$ dan $10 \mathrm{~cm}$ ditambahkan sebagai peredam intensitas radiasi primer dari beamport tembus yang masih cukup besar.
\end{abstract}

Kata Kunci: perisai radiasi, BNCT, MCNPX, laju dosis radiasi, beamport tembus.

DOI: $10.17146 / \mathrm{tdm} .2017 .19 .3 .3626$ 


\section{INTRODUCTION}

Cancer is the leading cause of death worldwide, with a total of 8.2 million deaths in 2012. The most common causes of death by cancer are lung cancer $(1.59$ million), liver $(745,000)$, stomach $(723,000)$, intestine $(694,000)$, breast $(521,000)$ and esophagus $(400,000)$ [1] .

Cancer is formed from damaged cells that should die, but continue to grow instead. These extra cells can divide without stopping and may form growths called tumors. This change is caused by several genetic factors and 3 categories of external agents, i.e. physical causes such as ultraviolet and ionizing radiation, chemical causes such as tobacco components, aflatoxin in food and arsenic in beverages and biological causes, such as infections from viruses, bacteria or parasites.

There are several methods of cancer treatment, depending on the type of cancer. Some types of cancer treatments can include surgery, radiation therapy, chemotherapy, immunotherapy, targeted therapy, hormone therapy, stem cell transplant and precision medicine.

In this research, a model radiation shield for the radiation therapy method called Boron Neutron Capture Therapy (BNCT) is presented. BNCT uses a non-radioactive boron-10 nuclide to capture the thermal neutron which then produce the ${ }^{10} \mathrm{~B}(\mathrm{n}, \alpha){ }^{7} \mathrm{Li}$ reaction. The reaction products are ${ }^{7} \mathrm{Li}$ dan ${ }^{4} \mathrm{He}$ which have a short range [2]. The product of the reaction is safe since the distance is only limited to the diameter of a cell [3].

The neutron source for BNCT can be obtained from nuclear reactors or accelerators. Technical document of IAEA explains that sufficient thermal neutron flux is needed to react with boron in the cancer cell. Epithermal neutron is used for the deep-seated tumor, while thermal neutron is used for tumor in the skin surface [4]. Existing BNCT facilities generally use nuclear reactor and accelerator-based neutron sources. In Indonesia there are three nuclear research reactors, all of them are operated by the National Nuclear Energy Agency of Indonesia (BATAN), they are the TRIGA 2000 reactor in Bandung, TRIGA MARK-II (Kartini Reactor) in Yogyakarta, and GA Siwabessy Multipurpose Reactor in Serpong. The Kartini Reactor is currently able to be utilized as BNCT facility [5].

Several studies have been conducted to design the collimator in the beamport of Kartini Research Reactor for BNCT [6-8]. Some of these researches produced designs that meet the IAEA criteria, as the Warfi's design (2015) which use 5 -cm-thick of $\mathrm{Ni}^{58}$ for the relector, 30-cm-thick of $\mathrm{S}^{32}$ for the moderator, $20-\mathrm{cm}$-thick of $\mathrm{Ni}^{60}$ for a filter, 2-cm-thick of $\mathrm{Bi}^{209}$ for gamma shielding and 3 -cm-thick of ${ }^{6} \mathrm{Li}_{2} \mathrm{CO}_{3}$-polyethylene as neutron shielding with the radius of aperture is $8 \mathrm{~cm}$ for in vivo in vitro test purposes. This design produces epithermal neutron flux of $1.13 \times 10^{9} \mathrm{n} / \mathrm{cm}^{2} \mathrm{~s}^{1}$. However, some part of design are still not in accordance with the International Atomic Energy Agency (IAEA) criteria, thus re-optimization need to be done. In contrast, Dwiputra (2015) modeled the radiation shield at the end of the thermal column on a previously designed collimator.

In this research the piercing beamport is used to direct radiation to the irradiation room. This room requires material around it, in order to reduce the radiation under the permitted threshold. The design made must comply with the applicable regulations of BAPETEN number 4 of 2013 article 15 , in which the dosage limit for radiation workers should not exceed the value of $20 \mathrm{mSv} /$ year. The radiation dosage resulting from the use of BNCT is essentially due to the interaction of radiation with matter by neutrons, gamma rays, beta and alpha.

In the design process of radiation shield, a design simulation should be performed. It aims to obtain a radiation shielding design with an output file that complies with the IAEA regulation in BNCT and also relates to the security and safety of both patients and workers at the BNCT facility as priority. This simulation was modeled on the Kartini reactor with the exact same specification as the original reactor. This simulation can save the estimated cost of installation of reactor components. In addition, it can avoid the high risk of radiation exposure. Therefore, this study was done by using Monte Carlo N-Particle code (MCNP) Version X program.

MCNPX is software which capable in simulating various nuclear processes such as fission reactions. In addition, the program is also capable in simulating particle interactions involving neutrons, photons and electrons. By using MCNPX, a neutron source in a form of critical state in reactor can be simulated. The radiation shielding design can also be done by utilizing MCNPX. 
Geometry and radiation shield materials can be varied to produce an output dosage that meets the BAPETEN requirements.

\section{METHODS}

The first stage in geometry modeling was to model reactor geometry. The reactor geometry modeling were done by making an input source, which consist of several parts of the reactor, such as reactor core, lazy susan, reflector and stand in the notepad program. The reactor was covered with a pool of water and coated by concrete on the outside. SSW Card and KCODE were used for reactor criticalization. 100000 particles were simulated with the assumption that reactor criticality is 1 , and with the skipped cycles is 60 for total cycles of 1000 . Reactor conditions were taken into account to calculate the criticality and the flux of the reactor.

The second stage in geometry modeling was to model the beamport geometry. The beamport used is a piercing beamport. The piercing beamport is formed as an air column that extends to the collimator and ends in the irradiation room. Shielding in the irradiation chamber was the focus of this study.

The third stage in geometry modeling was to model the collimator geometry. The collimator used in this study is a collimator previously designed by Arrozaqi (2013) with the specifications shown in Figure 1.

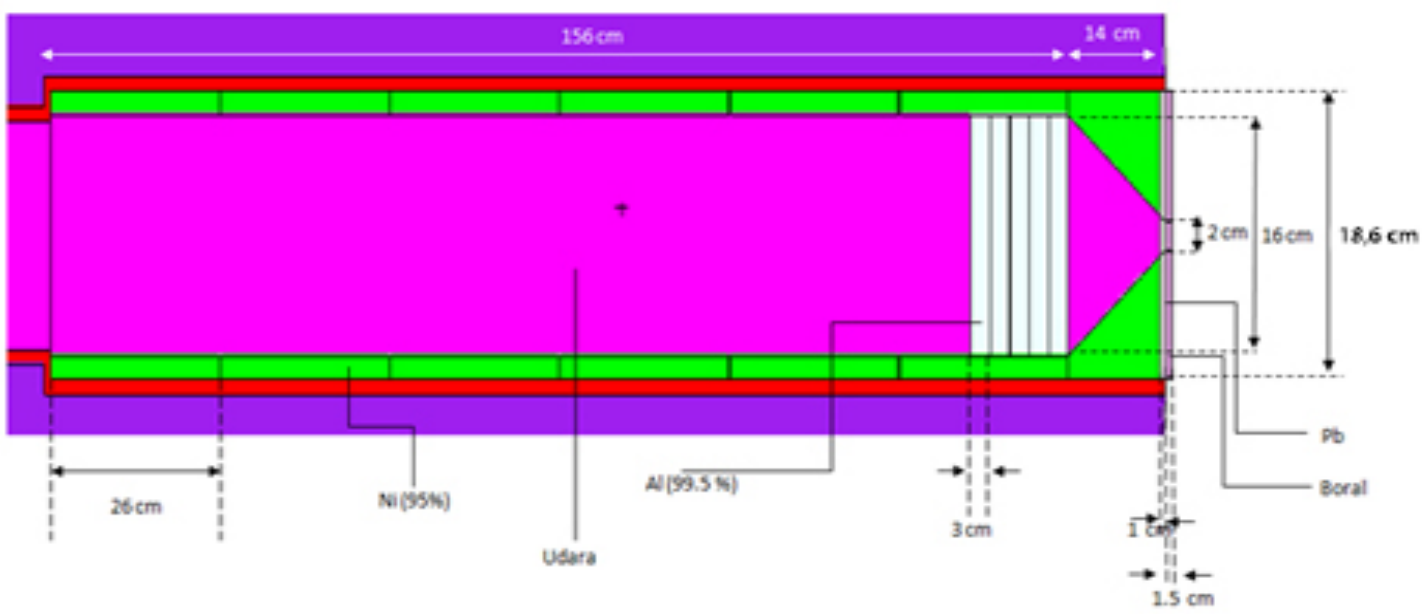

Figure 1. Predesigned Collimator for Kartini Research Reactor Neutron Source which was used in this study [9]

The fourth stage in geometry modeling was to model the irradiation room. The room used as an irradiation facility has a length of $30 \mathrm{~cm}$, a width of $30 \mathrm{~cm}$ and a height of $30 \mathrm{~cm}$ that has been adapted to the requirement of BATAN. The simulated room is only a blank space filled with air. Calculation of doses was made using materials that contain soft tissue (healthy tissue) which was placed around the room since the properties of radiation is isotropic, which spreads in all directions. After the fourth stages of modeling were done, then the modeling of input code could be run on the program Visual Editor.

The program was run to calculate reactor criticality and neutron flux yield at the outer ring of the reactor. Afterward, radiation shield modeling was then conducted.

The use of healthy tissue in the simulation with a thickness of $5 \mathrm{~cm}$ on the sides of the irradiation room was a model done by someone outside the irradiation facility. The calculation was done using a feature such as tally in MCNPX. The calculation of the F4 tally results in doses which was absorbed by biological tissue. The F4 tally output had been converted in Gy/s unit. The units of $\mathrm{Sv} / \mathrm{s}$ could be obtained by multiplying the equivalent dose rate with the quality factor [10]. 


\section{RESULTS AND DISCUSSION}

Initial doses obtained from MCNPX program are presented in Table 1.

Table 1. Epitermal Neutron Dose Rate Simulation Results Without Shielding

\begin{tabular}{cc}
\hline Side & Radiation Dose Rate $(\boldsymbol{\mu} \mathbf{S v} / \mathbf{j})$ \\
\hline Left & $6.34 \times 10^{2}$ \\
Right & $8.74 \times 10^{2}$ \\
Front & $4.42 \times 10^{3}$ \\
Up & $5.92 \times 10^{2}$ \\
Down & $6.74 \times 10^{2}$ \\
\hline
\end{tabular}

The considered materials were paraffin, barit concrete, 304 stainless steel and lead. These four materials are simulated against the neutron radiation which comes out of the aperture with a thickness variation from 10 to $200 \mathrm{~cm}$.

Simulation results are presented in graphs to facilitate the assessment of materials. The five simulated cells for tally calculations recording the rate of dose passing through the material are shown in Figures 2 (a-e).

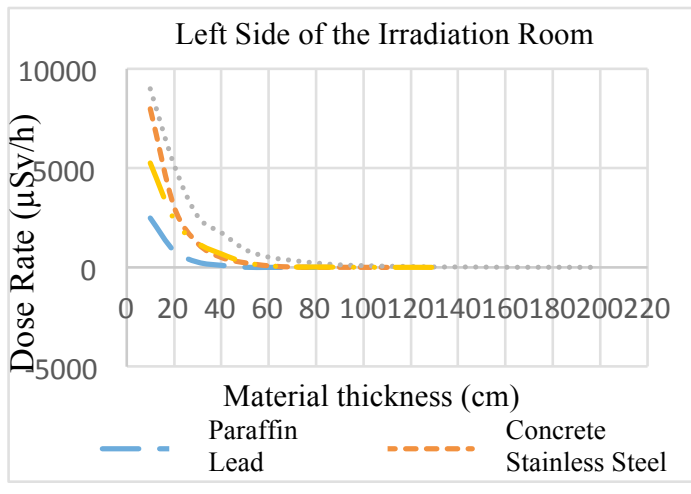

(a)

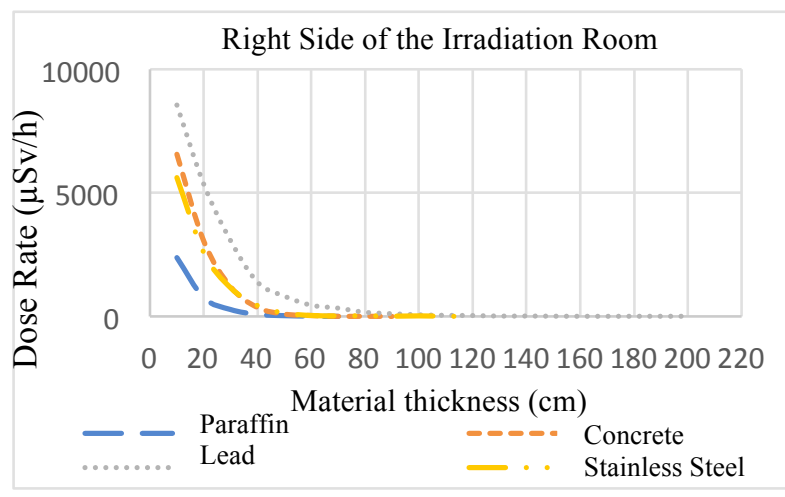

(b)

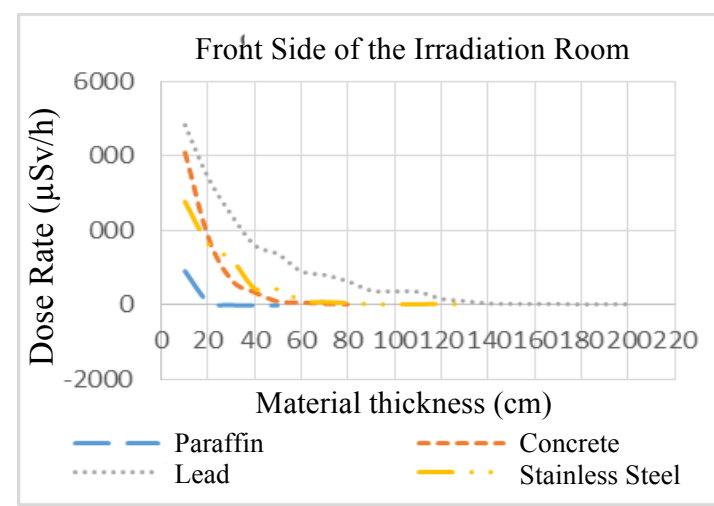

(c)

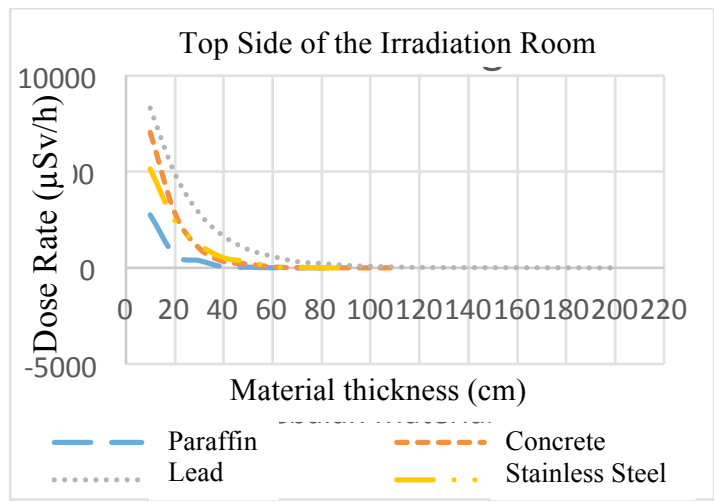

(d) 


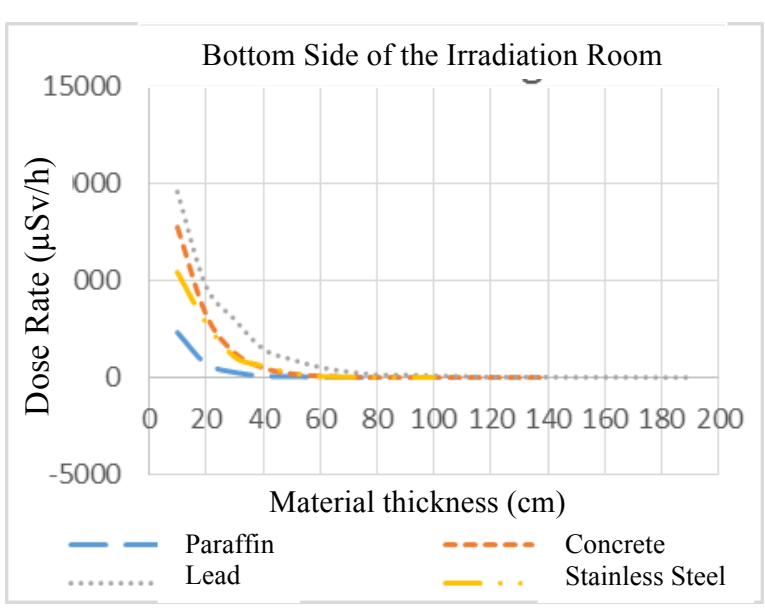

(e)

Figure 2. Radiation Dose Rate of Irradiation Room (a) on the Left Side (b) on the Right Side (c) on the Front Side (d) Rate on the Top Side (e) on the Bottom Side

Figures 2 (a-e) show that at a thickness of $40 \mathrm{~cm}$, paraffin has the best absorption since it is a good hydrocarbon compound to contain the radiation. All the images also show that concrete is very effective to withstand the rate of radiation dose at thickness of 30-100 cm. Stainless steel 304 has poor neutron uptake in Figures 2 to 6 so it can only dampen the dose rate up to $30 \mathrm{~cm}$ in thickness. Nevertheless, stainless steel 304 absorption is still better than lead, which has the worst absorption compared to other materials. Therefore in this research, lead did not use as a material for design.

The design of the radiation shield is made by combining the previously tested materials. Each design uses soft tissue which was divided into 21 sections and placed outside the radiation shield to record the leakage rate of the radiation. Division of soft tissue cells are as follows. Cell number $301,300,303,304,307$ to 310 and 313 to 324 are located on the right side of the room, on the left side of the room, above the room, below the room, and front of the room (beam catcher), respectively.

Design 1 uses the material paraffin with a thickness of $68 \mathrm{~cm}$ on the right side and a thickness of $70 \mathrm{~cm}$ on the left side as the main layer. An additional layer of paraffin with a thickness of $15 \mathrm{~cm}$ and $10 \mathrm{~cm}$ after the main layer is used to reduce the rate of the primary dose which is still large after going through the main layer, as in Figure 3.
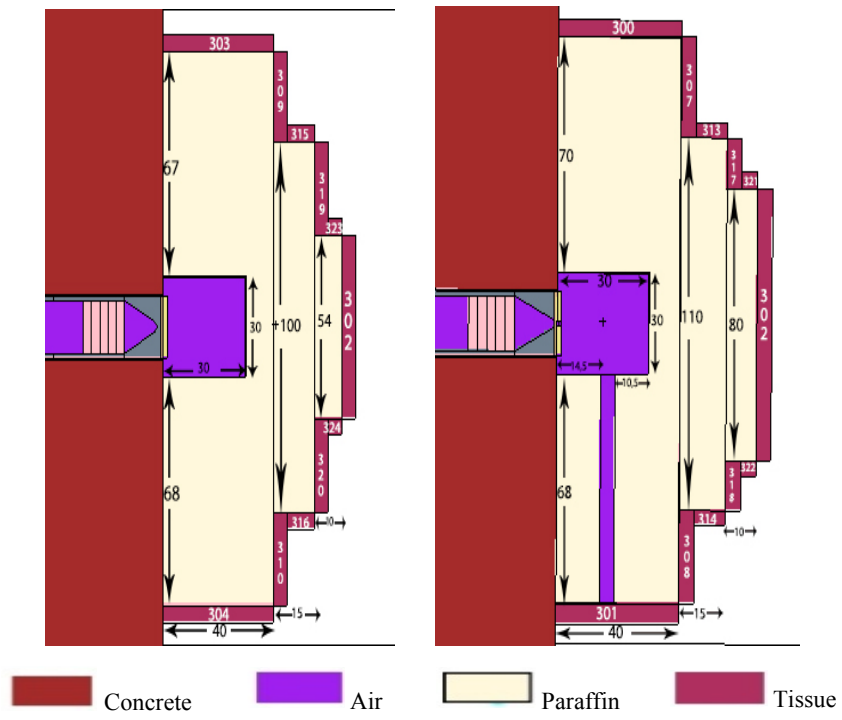

Figure 3. Top and Side View of Design 1 
The epithermal neutron dose rates of design 1 obtained using MCNPX can be seen in Table 2 .

Table 1. Epithermal Neutron Dose Rate of Design 1

\begin{tabular}{cccccc}
\hline Cell & $\begin{array}{c}\text { Dose Rate } \\
(\boldsymbol{\mu} \mathbf{S} / \mathbf{j})\end{array}$ & Cell & $\begin{array}{c}\text { Dose Rate } \\
(\boldsymbol{\mu} \mathbf{S} \mathbf{j} / \mathbf{j})\end{array}$ & Cell & $\begin{array}{c}\text { Dose Rate } \\
(\boldsymbol{\mu} \mathbf{S} / \mathbf{j})\end{array}$ \\
\hline 300 & 2.40 & 309 & 0 & 318 & 0 \\
301 & 8.20 & 310 & 0 & 319 & 0 \\
302 & 1.42 & 313 & 0 & 320 & 0 \\
303 & 4.98 & 314 & 0 & 321 & 0 \\
304 & 7.24 & 315 & 0 & 322 & 0 \\
307 & 0 & 316 & 0 & 323 & 0 \\
308 & 0 & 317 & 0 & 324 & 2.34 \\
\hline
\end{tabular}

Design 2 uses barite concrete as a material with a thickness of $100 \mathrm{~cm}$ on the left side and 98 $\mathrm{cm}$ on the right side as the main layer. An additional layer of barite concrete with a thickness of 35 $\mathrm{cm}$ and located about $25 \mathrm{~cm}$ after the main is a layer that is used to reduce the rate of primary dose which is still large after going through the main layer as in Figure 4.
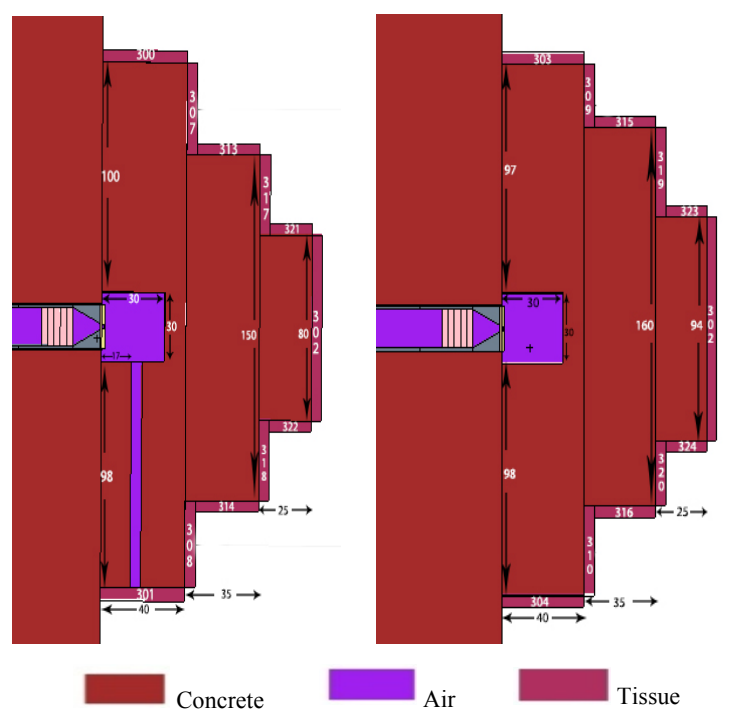

Figure 4. Top and Side View of Design 2

The epithermal neutron dose rates of design 2 obtained using MCNPX can be seen in Table 3 .

Table 3. Epithermal Neutron Dose Rate of Design 2

\begin{tabular}{cccccc}
\hline Cell & $\begin{array}{c}\text { Dose Rate } \\
(\boldsymbol{\mu} \mathbf{S v} / \mathbf{j})\end{array}$ & Cell & $\begin{array}{c}\text { Dose Rate } \\
(\boldsymbol{\mu} \mathbf{S v} / \mathbf{j})\end{array}$ & Cell & $\begin{array}{c}\text { Dose Rate } \\
(\boldsymbol{\mu} \mathbf{S v} / \mathbf{j})\end{array}$ \\
\hline 300 & 0.00 & 309 & 7.55 & 318 & 7.41 \\
301 & 0.00 & 310 & 5.51 & 319 & 32.01 \\
302 & 3.05 & 313 & 0.63 & 320 & 6.37 \\
303 & 1.17 & 314 & 2.50 & 321 & 13.27 \\
304 & 1.17 & 315 & 17.59 & 322 & 8.13 \\
307 & 3.11 & 316 & 1.87 & 323 & 23.67 \\
308 & 4.62 & 317 & 5.55 & 324 & 0.00 \\
\hline
\end{tabular}


Design 3 uses 304 stainless steel material with a thickness of $110 \mathrm{~cm}$ on the left side and a thickness of $108 \mathrm{~cm}$ on the right side as the main layer. An additional layer with a thickness of 65 $\mathrm{cm}$ and $45 \mathrm{~cm}$ after the main layer is used to reduce the rate of primary dose which is still large after going through the main layer as in Figure 5.

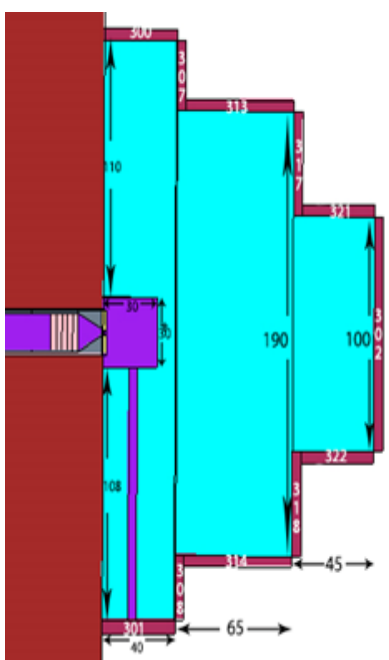

Concrete

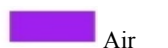

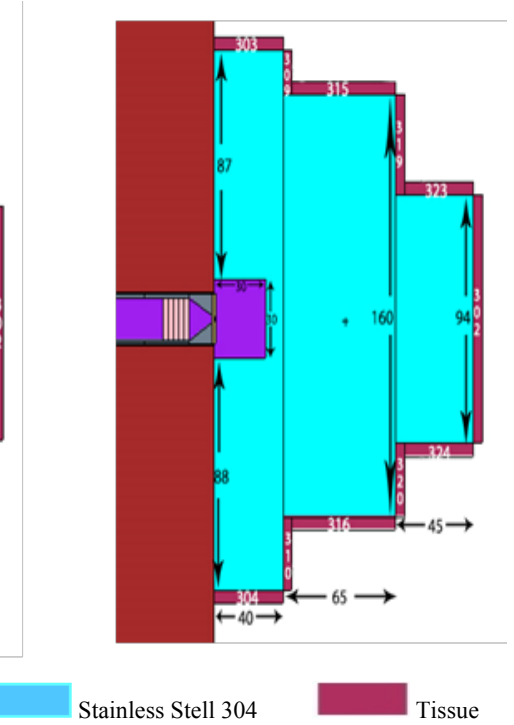

5. Top and Side View of Design 3

Epithermal neutron dose rates of design 3 obtained using MCNPX can be seen in Table 4

Table 4. Epithermal Neutron Dose Rate of Design 3

\begin{tabular}{cccccc}
\hline Cell & $\begin{array}{c}\text { Dose Rate } \\
(\boldsymbol{\mu} \mathbf{S v} / \mathbf{j})\end{array}$ & Cell & $\begin{array}{c}\text { Dose Rate } \\
(\boldsymbol{\mu} \mathbf{S} / \mathbf{j})\end{array}$ & Cell & $\begin{array}{c}\text { Dose Rate } \\
(\boldsymbol{\mu} \mathbf{S v} / \mathbf{j})\end{array}$ \\
\hline 300 & 0 & 309 & 34.47 & 318 & 8.08 \\
301 & 1.58 & 310 & 8.78 & 319 & 0 \\
302 & 0 & 313 & 4.54 & 320 & 4.56 \\
303 & 0 & 314 & 0.00 & 321 & 4.84 \\
304 & 1.25 & 315 & 7.37 & 322 & 0 \\
307 & 0.93 & 316 & 22.73 & 323 & 0.87 \\
308 & 5.00 & 317 & 26.70 & 324 & 0.29 \\
\hline
\end{tabular}

Design 4 uses a lead material with a thickness of $200 \mathrm{~cm}$ on the left side and a thickness of $198 \mathrm{~cm}$ on the right side as the main layer. An additional layer with a thickness of $80 \mathrm{~cm}$ and $45 \mathrm{~cm}$ after the main layer is used to reduce the rate of the primary dose which is still large after going through the main layer as in Figure 6. 

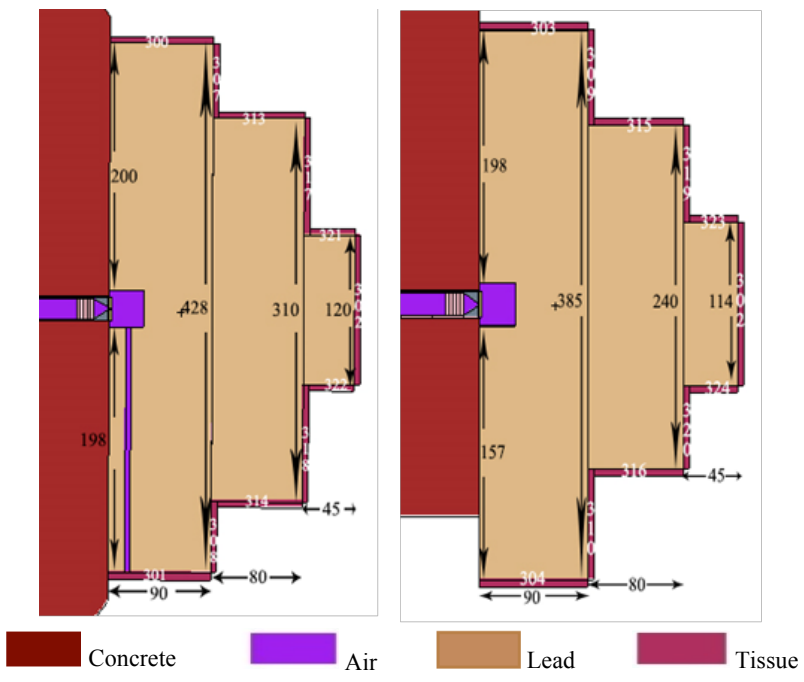

Figure 6. Top and Side View of Design 4

Epithermal neutron dose rates of design 4 obtained using MCNPX can be seen in Table 5.

Table 5. Epithermal Neutron Dose Rate of Design 4

\begin{tabular}{cccccc}
\hline Cell & $\begin{array}{c}\text { Dose Rate } \\
(\boldsymbol{\mu} \mathbf{S v} / \mathbf{j})\end{array}$ & Cell & $\begin{array}{c}\text { Dose Rate } \\
(\boldsymbol{\mu} \mathbf{S v} / \mathbf{j})\end{array}$ & Cell & $\begin{array}{c}\text { Dose Rate } \\
(\boldsymbol{\mu} \mathbf{S v} / \mathbf{j})\end{array}$ \\
\hline 300 & 0.89 & 309 & 21.31 & 318 & 45.68 \\
301 & 1.64 & 310 & 26.87 & 319 & 28.73 \\
302 & 1.47 & 313 & 13.00 & 320 & 51.95 \\
303 & 2.30 & 314 & 6.38 & 321 & 17.18 \\
304 & 0.94 & 315 & 23.12 & 322 & 16.08 \\
307 & 8.04 & 316 & 34.84 & 323 & 12.11 \\
308 & 7.63 & 317 & 12.09 & 324 & 6.67 \\
\hline
\end{tabular}

The results show that design 1 meets the criteria specified from BAPETEN since there is no leakage of dose rate. Therefore the dose rate on soft tissue under the regulation of BAPETEN is $10.42 \mu \mathrm{Sv} / \mathrm{j}$. The optimal model is chosen based on the largest dose rate, the highest radiation dose rate, the average radiation dose rate and estimate of the material cost for each radiation shield design. The best design chosen is based on a summary of all four designs in Table 6 and price of each shield design which is shown in Table 7 and Table 8, where assuming that 1 USD is equivalent to 13,558 IDR.

Table 6. Summary of all Radiation Shield Designs

\begin{tabular}{ccccc} 
& Design 1 & Design 2 & Design 3 & Design 4 \\
\hline $\begin{array}{c}\text { largest dose rate }(\mu \mathrm{Sv} / \mathrm{j}) \\
\text { the highest radiation dose rate (the } \\
\text { number of cell })\end{array}$ & 8.20 & 32.01 & 34.47 & 51.95 \\
Rata-rata laju dosis $(\mu \mathrm{Sv} / \mathrm{j})$ & 301 & 319 & 309 & 320 \\
\end{tabular}


The calculation results show that design 1 has the lowest maximum-radiation dose rate and the smallest average-dose rate. The largest radiation dose rate in design 4 is located in cell 320 which is at the bottom-front shielding beam catcher first layer.

Table 7. Shield Material Price per Kilogram (kg)

\begin{tabular}{cc}
\hline Material & Price per kilogram \\
\hline Paraffin & Rp. 13,558 \\
Barit Concrete & Rp. 7,846 \\
Stainless Steel 304 & Rp. 29,890 \\
Lead & Rp. 27,116 \\
\hline
\end{tabular}

Table 8. Cost Estimate Price All Radiation Shield Design

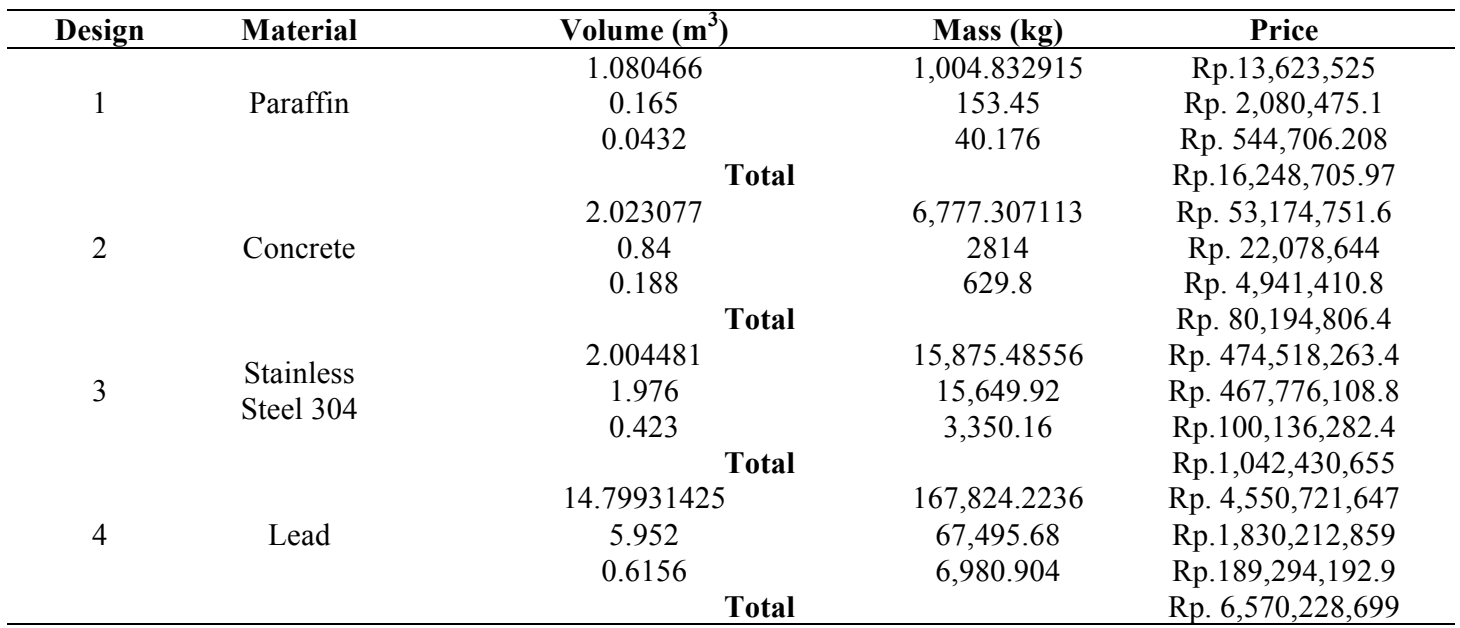

Design 1 is chosen as recommended optimal design with the lowest constraint price consideration. It is due to the thinnest of material used in design 1. In addition to that, design 1 does not have a dose leak in all soft tissues. The composition of designs in this study was based on dose test of 4 initial materials, which are stainless steel 304, paraffin, concrete and lead. These materials were selected based on previous studies in which they can be used as radiation shields due to their property, high cross-section of neutrons.Based on the results of the dose test that have been done on the material previously, it was obtained that the average dose for paraffin at thickness of $60-70 \mathrm{~cm}$ is 0 . In order to reduce the estimated manufacture cost thus design is proposed as $60 \mathrm{~cm}$ first layer, $15 \mathrm{~cm}$ first additional layer and $10 \mathrm{~cm}$ second additional layer. The first and second layers hold the main radiation in the irradiation room while the additional layer holds the direct radiation in the direction of the beamport. Simulation results on the second, third and fourth designs indicate a small dose leak on some soft tissues that can be optimized for further research. In order to reduce the leakage dose in concrete, stainless steel 304 , and lead material, thus the $90-100 \mathrm{~cm}, 100-110 \mathrm{~cm}$, and $190-200 \mathrm{~cm}$ of layer thickness are required, respectively.The dose leakage in the second, third and fourth designs are all located in cells 315 to 318 which are on the second layer of the beam catcher. Leakage of the beam catcher due to the type and thickness of the material in this section cannot withstand the scattering of the main neutron rate in the direction of the beamport. The neutron radiation discharge from the beamport has the possibility to form a semicircular construct with a neutron flux leading to a very large radiation shield. In this study, the four simulated designs are not really semicircular. The materials on the entire box-shaped design are arranged approaching the semicircle. The choice of box-shaped material is tailored to the actual shape.In other research conducted by Santoso (2014), the three designs have irradiated space dimensions of $50 \mathrm{x}$ $50 \times 50 \mathrm{~cm}$ which are too large and do not have the channels used to position the specimens in the 
irradiation room [11]. Therefore, this study uses a smaller irradiation space of $30 \times 30 \times 30$ and a $2.5 \mathrm{~cm}$ diameter duct for the specimen. The room and the main layer are $2 \mathrm{~mm}$ thick aluminum coated to reduce the heat which can cause the paraffin material to melt. Four types of choosen materials were tested on the first design with an additional layer to prevent the dose leakage in up to 4 designs. The calculations of dose rates that have been done on all four designs are still within the scope of neutrons only. Therefore calculation of photon dose rate for each design is still not optimal.

\section{CONCLUSION}

Design 1 is considered as the best radiation shield design modeling with piercing beam neutron source for BNCT facility. Its largest radiation dose rate is $8.20 \mu \mathrm{Sv} / \mathrm{hr}$. The highest rate of radiation dose in the first design is still below the threshold allowed by BAPETEN, which is $10 \mu \mathrm{Sv} / \mathrm{hr}$. Therefore, the first design is safe for radiation workers if outside the irradiation facility within a certain time. It is concluded that paraffin can hold neutron radiation. Paraffin, barite concrete, 304 stainless steel, and lead can withstand radiation at a thickness of $40 \mathrm{~cm}, 50 \mathrm{~cm}, 60 \mathrm{~cm}$ and 180-200 cm, respectively. Design 1 has an irradiated room dimension of $30 \times 30 \times 30 \mathrm{~cm}$, a radiation shield with paraffin material that has a thickness of $68 \mathrm{~cm}$ on the left and bottom, $70 \mathrm{~cm}$ on the right side, $45 \mathrm{~cm}$ on the front side, and $67 \mathrm{~cm}$ on the upper side.

\section{ACKNOWLEDGEMENTS}

We would like to thank to the Center for Accelerator Science and Technology, National Nuclear Energy Agency (BATAN) Yogyakarta, Indonesia for supporting this study.

\section{REFERENCES}

1. National Cancer Institute. About Cancer: What Is Cancer? [accessed: 19 November 2015]. Available from: https://www.cancer.gov/about-cancer/understanding/what-is-cancer/

2. Rasouli, F. S. \& Masoudi, S. F. Simulation of the BNCT of Brain Tumors Using MCNP Code: Beam Designing. Iranian Journal of Medical Physics. 2012. 9(3), pp. 183-192.

3. Sauerwein, W. A. G. Principles and Roots of Neutron Capture Therapy. In: Neutron Capture Therapy. Essen: Springer. 2012. p. 1.

4. IAEA Current Status of Neutron Capture Therapy. Vienna, Austria: International Atomic Energy Agency; 2001.

5. Fauziah, A. A. Conceptual Design of Neutron Collimator in Termal Column of Kartini Research Reactor for Boron Neutron Capture Therapy. Yogyakarta: Department of Engineering Physics Gadjah Mada University; 2013.

6. Pamungkas, V. S. H. Simulasi Rancang Bangun Kolimator pada Beam port tembus Reaktor Kartini untuk Uji In Vivo Boron Neutron Capture Therapy. Yogyakarta: Department of Physics Gadjah Mada University; 2016.

7. Maharani, C. Perancangan Kolimator Singgung pada Beamport Singgung Reaktor Kartini untuk Boron Neutron Capture Therapy. Yogyakarta: Department of Physics Gadjah Mada University; 2014.

8. Warfi, R. Optimasi Kolimator Kolom Termal untuk Fasilitas Uji In Vivo dan In Vitro Boron Neutron Capture Therapy (BNCT) di Reaktor Kartini Menggunakan Simulator MCNP-X. Yogyakarta: Department of Engineering Physics Gadjah Mada University; 2015.

9. Arrozaqi, M. I. M. Perancangan Kolimator di Beamport Tembus Reaktor Kartini untuk Boron Neutron Capture Therapy. Yogyakarta: Department of Engineering Physics Gadjah Mada University; 2013.

10. Dwiputra, M. I. M. A. Pemodelan Perisai Radiasi Fasilitas Boron Neutron Capture Therapy dengan Sumber Neutron kolom Termal Reaktor Kartini Menggunakan Simulator Monte Carlo $N$ Particle Extended. Yogyakarta: Department of Engineering Physics Gadjah Mada University; 2015.

11. Santoso, B. H. Pemodelan Perisai Radiasi Fasilitas BNCT dengan Sumber Beamport Tembus Teras Reaktor Kartini Menggunakan MCNP5. Yogyakarta: Department of Engineering Physics Gadjah Mada University; 2014. 